\title{
ロ腔領域疾思への半導体レーザーの使用経験
}

\section{Clinical Use of the Diode Laser in Oral Surgery}

中野健介、橋本賢二，富榢謙一，塩田重利

Kensuke Nakano, Kenji Hashimoto, Ken-ichi Tomitsuka, Shigetoshi Shioda

東京医科脒科大学歯学部第一口腔外科学教室

The First Department of Oral Surgery, Faculty of Dentistry, Tokyo Medical and Dental University

The diode laser was used in treating 110 cases of oral and maxillofacial diseases(including 36 diseases of nervous system, 20 postoperative complications, 17 inflammation, 33 temporomandibular arthrosis and 7 glossodynia).

The diode laser exerted effects on 24 cases of nervous system diseases, 14 cases of postoperative complications, 8 cases of inflammation, 16 cases of temporomandibular arthrosis and 3 cases of glossodynia. And significant effects were obtained in 4 cases of the trigeminal neuralgia and 2 cases of the hypesthesia. In these cases symptoms almost disappeared immediately after radiation. Also the diode laser had great therapeutic effects on myogenic trismus, muscular pain and contraction with temporomandibular arthrosis. And this therapy inflicted neither pain nor side effects on all patients.

Therefore it seemed that the diode laser therapy was safety and availabe for treating diseases of nervous system, postoperative comolications, inflammation and temporomandibular arthrosis.

\section{〔緒言〕}

1968 年, Mester がルピーレーザーの低エネル ギー $\left(1 \mathrm{~J} / \mathrm{cm}^{2}\right)$ 照射により，動物の毛の発育が促進 するのを発見して以来，各種低出カレーザー(ソ フトレーザー）の作用，応用に関して多くの研究 がなされている。

なかでも，レーザーダイオードを使用した半導 体レーザーは小型, 軽量, 安価な装瞋を作製でき るなどの長所を有しており, 種々の計測機器, レ 一ザー治療装置に利用されている。
表 1 半導体レーザーの作用と応用

創傷治癒の促進：難治性謴痬等への応用

消炎・鎮痛：炎症性疾患への応用

末梢缩環の改善：皮并等への応用

神経症状の緩解：神経疾患への応用

筋粲張の緩和：筋性疼痛・顎関節症等への応用

その臨休医学的作用としては表 1 に示すように 
創傷治癒の促進作用，消炎・鎮痛作用，末梢循環 改善作用, 神経症状の緩解作用, 等緊張の緩和作 用などがあげられておう，臨床各科で種々の疾患 の治療に応用されつつある。今回，われわれは吉 田慗作所の試作した半導体レーザー装置を使用し， 口腔領域諸疾患 110 例の治㞠を行い，その効果を 検討したのでその概要を報告する。

\section{〔装置〕}

表 2 仕様

$$
\begin{aligned}
& \text { ダイオード : GaAlAs } \\
& \text { 中心波長 }: 905 \mathrm{~nm} \\
& \text { ヘルス : } 1.5 \mathrm{KHz} \quad 200 \mathrm{~ns} \\
& \text { ピーク出力: } 10 \mathrm{~W}
\end{aligned}
$$$$
\text { 平均出力 : } 0.5 \sim 1 \mathrm{~mW}
$$

表 2 に今回使用した半導体レーザー装置の仕様 を示す。本機は，素子にGaAlAsレーザーダイオ ードを使用した中心波長 $905 \mathrm{~nm}$ ，ピーク出力10W， 平均出力 $0.5-1 \mathrm{~mW}$, パルス $1.5 \mathrm{KHz}, 200 \mathrm{~ns}$ の 半導体パルスレーザー装置で, $\mathrm{AC} 100 \mathrm{~V}, 10 \mathrm{~W}$ で 作動する。プローブ先端にダイオードが装着され て㧍り，タイオードから $15 \mathrm{~mm}$ 前方に $3 \times 4 \mathrm{~mm}$ の焦 点を結ぶ。

また，電気抵抗を応用した経穴探索装置が内蔵 されて㧍り，取穴が容易に行える。

[症例]

昭和59年 4 月より昭和 60 年 8 月までに当科にて ソフトレーザー治療を行い, 効果判定しえた症例 は 110 例であった。症例の内訳は, 男性29例, 女 性81例で，年龄は15-82藏，平均年龄40.7藏であ った。表 3 に疾患別症例数を示す。

\section{〔治療法〕}

治療にあたっては，各症例の症状に応じ，経穴 （表 4 ）や患部局所に 3-60分のレーザー照射を 3 日から 3 週間招きに繰返し行った（表 3 ）。以 下にその疾患別治療法の概略を示す。

\begin{tabular}{|c|c|c|c|}
\hline & & & 取 穴 部 位 \\
\hline \multirow[t]{2}{*}{ 神 } & $\equiv$ & 第 I枝 & 眼窩上孔（陽白） \\
\hline & 叉 & 第 II 枝 & 眼䈑下孔（四白), 切歯孔 \\
\hline \multirow[t]{2}{*}{ 経 } & & & 人中，鼻翼基部（迎香） \\
\hline & 神 & 第回枝 & オトガイ孔，下唇下部陷凹 \\
\hline 疾 & 経 & & 部（承漿） \\
\hline 患 & \multicolumn{2}{|c|}{ 顔面神経 } & 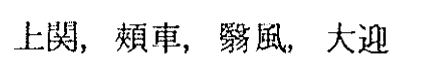 \\
\hline \multicolumn{3}{|c|}{ 擷関節症 } & 下関, 頓車, 風池, 天容 \\
\hline
\end{tabular}

表 3 症例

\begin{tabular}{c|r|l}
\hline 疾患名 & 症例数 & \multicolumn{1}{|c}{ 治療法 } \\
\hline 神経疾患 & 36 & レーザー鍼治療 \\
\hline $\begin{array}{c}\text { 術後継発症 } \\
\text { 晾面関節症 }\end{array}$ & 20 & $\begin{array}{l}\text { レーザー鍼治療 } \\
\text { 患部への局所照射 }\end{array}$ \\
\hline $\begin{array}{c}\text { 炎症性疾患 } \\
\text { 舌痛症 }\end{array}$ & 14 & 患部への局所照射 \\
\hline 計 & 110 & \\
\hline
\end{tabular}

表 4 レーザー鍼治療時の取穴部位

\section{[伸経疾患]}

表 4 に示した経穴にいわゆるレーザー鍼治寮を 施行した。症状の軽減があり得られない症例に 対しては A T P 製剤, ビタミンB剤などの投与を 行った。

\section{[手術後継発症]}

神経疾患と同様のレーザー鍼治療を中心に症状 に応じて患部への局所照射, 薬物療法を併用した。 [顎関節症]

レーザー鍼治療と顎関節および䍉への局所照射 を行った。咬合に起因すると思われる症例には， 
咬合挙上床などを併用した。

\section{〔炎症・舌痛症〕}

炎症・舌痛症には，罹患部への局所照射を単独 で，あるい性薬物療法等との併用療法として施行 した。

\section{〔効果判定基準〕}

著効：ほぼ完全に症状の消失したもの。

有効：50\%以上症状が改善したもの。

微効：効果は認められるものの, 症状の改善度 が50\%末渵のもの

無効：効果のないもの。

\section{〔結果〕}

表 5 に治療成績を示す。

神経疾患では36例中 24 例（66.7\%）に，術後継 発定では20例中14例（70.0\%）に効果を認めた。 特に三叉神経痛の 3 例, 知覚鈍麻の 1 例, 術後の 知覚麻痖の 1 例に照射直後ほぼ泟状が消失するな ど著明な効果を示した。しかし, 術後の神経麻瘏

- 知覚鈍麻のうち, 神経が切断・損傷されたと思 われる症例には効果がなく下顎智爾に関連した症 例にも無効であった。

炎症性疾患においては，14例中 8 例 ( $57.1 \%$ ) に疼痛の軽減などの効果を認めたか，慢性下領骨 骨䯣炎および歯槽骨炎の 1 例は薬物療法と併用し ており，レーザーのみの効果とは判定できなか。 た。

靧関節症では，33例中16例（48.5\%）に効果を 認め, 特に良好な効果を示した 8 例中 7 例は，筋 性要因の考えられる掟例であった。また，頭関節 症に伴亏筋肉症状にも良好な効果を示した。

舌痛症は， 7 例中 3 例に有効であった。

また，今回治療を行った110例に招いて，照射 時に苦痛を訴えたり，副作用の見れた症例はなく， 照射部之その周辺に一過性で軽度の局所熱感と発 赤がみられたのみであった。

\section{〔考察〕}

現在一般に行われている口腔領域疾患の治療法 には，薬物療法，手術療法，理学療法などがある。
表 5 治療成績

\begin{tabular}{|c|c|c|c|c|c|c|}
\hline & 病名 - 症状 & 総数 & 著効 & 有効 & 徽効 & 無効 \\
\hline 神 & $\begin{array}{c}\text { 三叉神経痛 } \\
\text { 三叉神経痛様疼痛 }\end{array}$ & 26 & 4 & 10 & 5 & 7 \\
\hline 経 & 知覚麻痺 - 鈍麻 & 6 & 1 & 1 & 1 & 3 \\
\hline 疾 & 顔面神経麻痺 & 4 & & 2 & & 2 \\
\hline 患 & 計 & 36 & 5 & 13 & 6 & 12 \\
\hline & 神経痛样疼痛 & 7 & & 3 & 2 & 2 \\
\hline 粫 & 知覚麻盘 - 鈍麻 & 9 & 1 & 2 & 3 & 3 \\
\hline 後 & 顔面神経麻盘 & 1 & & & & 1 \\
\hline 継 & 䇟 症 状 & 2 & & 2 & & \\
\hline 発 & 浮腫 & 1 & & & 1 & \\
\hline 证 & 計 & 20 & 1 & 7 & 6 & 6 \\
\hline & 慢性下罘骨·骨髄炎 & 3 & & 1 & 1 & 1 \\
\hline 资 & 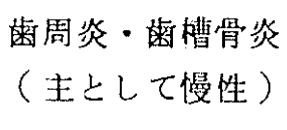 & 8 & & 2 & 4 & 2 \\
\hline & 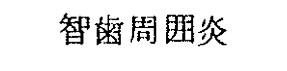 & 2 & & & & 2 \\
\hline 症 & 買 関節 炎 & 1 & & & & 1 \\
\hline & 計 & 14 & & 3 & 5 & 6 \\
\hline & 顎 関 節 症 & 33 & 3 & 5 & 8 & 17 \\
\hline & 舌 痛 症 & 7 & & 3 & & 4 \\
\hline & 計 & 110 & 9 & 31 & 25 & 45 \\
\hline
\end{tabular}


今回行った半導体レーザーによる治療法は, 理学 療法の範眼にはいるもので極めて弱いレーザー光 を使用しており，生体への侵襲がなく次のような 長所があるとされている。

1）感染の危険がない。

2）副作用かなく安全である。

3）操作が簡単で熟練を要さない。

4）無痛である。

今回レーザー治療を行った 110 例においても， 照射により苦痛を訴えたり副作用の現れた症例は なく，半導体レーザー治療時の安全性が確認でき た。照射部周辺の一過性で軽度の熱感と発赤は, 弱いレーザー光の生体刺激作用 (自律神経刺激) により，神経支配領域の血流が增加したためと思 われる。この現象は末梢循環の改善を示唆してお り，レーザー光の消炎機序と何等かの関連がある と推測される。

炎症性疾患の治療においては，その疼痛の軽減 に効果を示した。しかし，中等度から重度の炎症 に本治療法を単独で使用することは危険であり， また，感染症の上うに原因の明らかなものへの単 独療法も非合理的である。このような場合には主 療法として薬物療法などを行い，補助的寮法とし てレーザー治療を行うことが望ましく，併用によ り相乗的消炎作用や楽物量の減量が期待される。

また，急性炎症にレーザー治療を行った場合， 腫脹が増大寸ることが考えられるので注意が必要 である。

神経疾患では、レーザー治療は有効と思われた。 レーザー光の神経への作用は，まだ不明な点も多 いか，神経疾患の治療法に安全，確実なものがな い現在, 効果的で安全, 簡便な本療法は, 治療の 初段階において第一選択されるべきものと考えら れる。

術後楼発症では，筋症状や神経自体に損㑺がな く，術後の反応性の炎症に起因したと考えられる 神経症状に有効と思われた。下顎智菌拔歯後の神 経痛様疼痛，知覚麻瘦には無効であったが，これ は患部が骨に围まれているのでレーザー光が到達 できないためと推察される。
罘関節应においては，筋性要因が強いと考えら れる症例や買関節症に伴与筋症状に良好な効果を 示した。このことは，半導体レーザーの竻への作 用を示唆しており，低出カレーザーは筋緊張の緩 和作用を有し, 筋性疼痛や等性の䫇関節症に効果 があるとの報告もあることから，顎関節症の治療 に半導体レーザーは有用と思われた。

しかし，䫇関節症はその発症に咬合が関与寸る ことが多く、レーザー治療は原因療法とならない ため，咬合挙上林など現行の治療法との併用が必 要と思われる。

舌痛症は有効例もみられるが，症例が少ないの で今後症例を增やし㭘討する予定である。

\section{〔結語〕}

以上, 口腔領域各種疾患 110 例への半導体 $レ$ ザーの使用経験から，半導体レーザーによる治療 法は無痛, 安全, 簡便で口腔領域の神経疾患, 手 術後の継発症, 炎症性疾患, 顎関節症の治療に有 用と思われた。

神経疾患に安全で㫿実な治療法がない現段階で は安全, 簢便な本療法は, 第一選択する価值があ るものと考えられた。

頱関節症，炎症に関しては疼痛の軽减を認め, 補助的治療法として楽物療法などと併用すること により，相乗的効果，薬物量の減量（投与量，投 与期間等 ), 治療期間の短縮が期待できると思わ れた。

\section{(文献)}

1）兵藤正義：痛みの新しい治療法－東洋医学の 近代的応用, 中外医学社, 東京, 87-105, 1969

2）渥美和彦監修：レーザーの臨休，メディカル プランニンク，札㹸， 37-38，1981

3) P $\log$ F.M.W. : Laser in Medicine, Editor : Koebner H.K., John Wiley and Sons, Chiches ter-New York-Brisbane-Toron to, 21-37, 1980

4）中野健介，橋本賢二他：炎症モデルにおける 半導体レーザーの効果, 日本レーザー医学会誌 Vol. 5, No. $3: 237-242,1985$

5）中野健介，橋本賢二他：半導体レーザーによ る三叉神経痛の治療経呀, 慢性疼痛研究会誌, Vol. 3, $\mathbb{6}_{0.1}: 28-30,1984$ 